\section{I $\mathbf{B} \mathbf{A}$ Institute of \\ Yk Business Administration \\ तर Karachi \\ Leadership and Ideas for Tomorrow}

Article 9

Volume 9 Issue 1 January-June 2014

$1-1-2014$

\title{
Lays: Halal/haram crisis
}

Jami Moiz

Institute of Business Administration, Karachi

Nida Aslam Khan

Institute of Business Administration, Karachi

Follow this and additional works at: https://ir.iba.edu.pk/businessreview

Part of the Marketing Commons

(c) (i)

This work is licensed under a Creative Commons Attribution 4.0 International License.

\section{Recommended Citation}

Moiz, J., \& Khan, N. A. (2014). Lays: Halal/haram crisis. Business Review, 9(1), 110-118. Retrieved from https://doi.org/10.54784/1990-6587.1232

This article is brought to you by iRepository for open access under the Creative Commons Attribution 4.0 License and is available at https://ir.iba.edu.pk/businessreview/vol9/iss1/9. For more information, please contact irepository@iba.edu.pk. 


\title{
CASE STUDY
}

\section{Lays: Halal/Haram Crisis}

\author{
Jami Moiz \\ Institute of Business Administration, Karachi \\ Nida Aslam Khan \\ Institute of Business Administration, Karachi
}

\begin{abstract}
The following case revolves around Frito Lays which is a highly popular Snack-food Company in various Muslim nations. One of Frito Lays biggest brands, Lays Potato Chips, is a major competitor in the Pakistani Snackfoods market. However in 2009, Lays faced a major controversy when it was targeted with a campaign saying that an ingredient found in the manufacturing is Haram (prohibited for Muslims). This claim proved to be disastrous from Lays as it meant a loss in the consumer base as well as a dent onto the Brand's image amongst its wide base of Muslim consumers. The case further goes on to explain the background, the controversy as well as the strategy, Lays' Brand Managers formulated in order to deal with this dilemma in a fashion that was both tactful and strategic in nature.
\end{abstract}

Key lessons to be extracted from this case study for brands dealing with consumer goods are that Pakistani companies need to:

- Chalk out a PR strategy/system to prevent the assortments of media from defaming brands and their respective products.

- Have a system in place where edible consumer items are validated and certified as Halal (Allowed for Muslims) as this would guarantee absolutely no 'Brand-Assassination'.

- Have in place an effective and efficient Public Relations Department which can strategically handle and consequently resolve controversies similar to the one that Lays faced in 2009.

\section{Literature Review}

The literature review regarding consumer attitudes and preferences across the Muslim world indicates that with increasing religious awareness among Muslims across the world the need for Halal Certification of products has become more meaningful than even ISO or similar certifications. (Shafie \& Othman, 2006). In the UAE, there is a rising concern regarding the labeling and certification of Halal Products as awareness rises (Ireland \& Rajabzadeh, 2011). According to (Ireland \& Rajabzadeh, 2011):

"Halal food comes from religiously acceptable food categories, is safe and not harmfully prepared. Prohibited food includes swine and all products derived from swine, blood, alcohol and intoxicants of all types. Some exotic prohibitions are carnivorous animals with fangs, birds of prey with talons, land animals without external ears (generally reptiles and amphibians), carrion, food dedicated to idols and all insects except locusts. Animals must be slaughtered by a Muslim who pronounces the name of Allah as he kills the animal using Islamic methods (Zabiha) that kill painlessly as they remove all blood from the carcass. 
Humane handling must also be practiced and animal suffering minimized. Foods are also prohibited if they are contaminated or contain any of the "questionable ingredients" which include a number of pork-derived food additives including gelatin, glycerin, emulsifiers, enzymes and many flavorings. Preservatives are also questionable, as well as other products used in the production of food including processing aids, lubricants, cleaning agents, and packaging material.

For any product to be labeled as Halal it must run through a comprehensive application and testing program. Many countries have their own halal certification programs, in due course the Halal certification authorities of certain countries have become Key Sources of Halal Certification internationally. Particularly the Malaysian Halal authority (JAKIM) for central and east Asian countries, South African National Halal Authority (SANHA) in the African continent and the Islamic Food and Nutritional Council of America (IFNCA) for North-American have become internationally acclaimed as leading authorities for Halal Certification.

In general, The Halal Certification process is a step by step procedure where an organization must apply to a certification authority for the halal certification of its products. The Authority then evaluates the information and procedures used to ensure halal production of the product. They may require the organization to disclose further information the given data seems insufficient. After complete disclosure of production processes, inspections are organized to ensure complete compliance with Halal Requirements. Finally the Certification Authority permits the company to use its seal of approval on the company's products. The Halal Certification Authority may then conduct audits of the applicant in the future to ensure ongoing compliance with Halal Procedures.(SANHA)(Halal Authority Board, 2012)

\section{Objectives}

Lays $^{1}$ is a very popular edible consumer product in many countries, including Muslim countries like Pakistan and Saudi Arabia. It owns 4 leading brands, Lays, Cravy's, Cheetos and Kurkure, with a total of 14 different Stock Keeping Units (SKUs) in its portfolio. Lays chips may be a relatively new player in Pakistan, but since it entered the market in 2006 and until the start of 2009, it has managed to make a name for itself among the leading potato chip brands such as 'Super Crisps', a brand of TrippleEm (Pvt.) Ltd.; 'Kurleez', brand of Snack City Ismail Industries (Pvt.) Ltd. and 'Slanty', brand of K.S Sulemanji and Esmailji (Pvt.) Ltd Pakistan. Priced at a point of a mere five rupees, it seems that Lays was able to extend its market well beyond its traditional, urban 16-24 year old target segment and instead reach mass appeal.(Exhibit 1) (Brand Manager, 2012)

Having invested \$50 million in its Sundar plant, Lays began its local production in 2007 and was on a spree for high growth when it seemed like it received a hard hit from one of the medical research institutes of Pakistan. This massive blow revolved around overcoming a heavy controversy that deemed Lays to contain pig fat (an ingredient forbidden for Muslims.)(Haque, 2009) 
Henceforth, Frito Lays had to resolve two highly significant dilemmas:

1. Religious barriers: Being a Muslim country, such a report was to receive harsh criticism for Lays with a devastating impact on its sales volume. Not only was the older age group (35 and above) concerned by such news but the younger population took it seriously as well and this perception had to be tackled and completely removed from the minds of Lays' consumers.

2. Political barrier: Furthermore, Pakistan being a country quite known for its political instability and riots meant that the population here is extremely violent about such grave issues and might even come out on the roads to protest. In such cases, the government might altogether ban the production and sales of 'Lays', leading to total boycott of this high sales generating product.(SK, 2009)

Furthermore, in the month of April 2009, Dr. Amjad Khan of the "Medical Research Institute, USA" claimed that Pakistani-manufactured Lays chips contained the ingredient E631 which, he claimed, was derived from pig fat. Dr Khan went on to label the brand as haram and hence unsuitable for consumption by Muslims.

The news spread like wild fire through text messages and blogs until retailers and people involved in the distribution network of Lays started sending threats for boycotts (Exhibit 2). By August 2009, the nation had staged protests, many religious scholars had been interviewed and the protests were covered by a number of TV channels across the country. Even Lahore High Court had issued a letter to the company inquiring the authenticity of the reports and famous channels like 'Al Huda','Aaj' and 'Express' had given it adequate coverage, further defaming the company as well as its sales.(Brand Manager, 2012) In reality, E631 is a flavoring ingredient which can be made using multiple methods including animal fat or plant material, and the E631 ingredient used in making Lays chips is derived from tapioca starch (plant material). It is also worth mentioning here that many other products in the market, including soups and chicken cubes use E631.(E631 : Sodium inosinate, 1999) Continuous tracking of Dr. Amjad Khan's claim was carried out by persistent efforts through South African National Halal Authority and the Islamic Food and Nutritional Council of America. Absence of any results suggested that the email could have been nothing but an orchestrated attack on the brand.(Haque, 2009)

The following objectives were set to meet these challenges:

1. Clarify through communication: Hire a PR agency with an effective communication strategy to convey to people that the pig fat controversy was wrong and inapplicable in this case.(Exhibit3\&4)

2. Retain customers: Many people wanted to play it safe Henceforth a breakthrough strategy like a celebrity endorsement perhaps had to be effectively worked with.

\section{Initial Strategy}

Speaking about this dilemma, the Head of Marketing for PepsiCo Foods in Pakistan and Afghanistan, Muhammad Saad Khan informed that "....it was high time something was done about this since there was already a $30 \%$ decline felt in the sales of Lays, after \$12million had been spent in August 2009 to raise the capacity."(Khan, 2012) Not only that, Muhammad Saad also stated in the interview that the demand for Lays had lowered tremendously over this particular period as assortments of educational and civil institutions 
were unwilling to buy their product. To top it all, even the distribution vans were forced to stop the delivery. Not only that, multiple delivery vans were stopped from operating in Karachi, Lahore, Rawalpindi and Islamabad and about 25 stores in these metropolitan cities were attacked for selling Lays. Such a negative propaganda had a spillover effect on other brands of Pepsi and it was high time something was done otherwise Pepsi might have to pull out of Pakistan entirely.

The initial strategy was to form a crisis management team (CMC- Corporate and Marketing Communications) on the PR front and to have an advertising agency such as 'Interflow Communications' to spearhead the advertising front. The role of this team was to communicate that contrary to rumors, the brand was not haram.

In around mid-May, Frito Lays made available to the press a series of endorsements it had obtained from international and local scientific and religious authorities clarifying that Lays chips were halal in nature. In conjunction with these efforts, Lays released a small-scale print right on the front page of Dawn saying 'Lays comply with the Shariah Council requirements and are therefore 100\% Halal.' Such advertisements were having a backward spiral effect on the company as many people who were previously unaware of the controversy were now aware of it and got to know about this substantial issue. (Exhibit 4)

Also, none of these advertisements mentioned the very ingredient E631, which was the root cause of the problem. The print ad should definitely have mentioned this, and then the online version would have delved into the intricacies of this compound and why it isn't Haram in detail.

The TV and poster campaign that focused on these endorsements. In addition, letters were mailed to retailers and distributors refuting the allegations made in Dr Khan's email.(Exhibit5)

Also, Muhammad Saad along with his Marketing Department went further to hire a reputable law firm so that it can effectively handle the in-court cases while the Marketing Team strategized to bring the sales percentage back to its original point. In addition to this, to tackle this problem further, Lays got an endorsement from PCSIR and SANHA and got it printed onto its packet. This addressed the First Moment of Truth as the consumers immediately referred to the contents at the back. (Brand Manager, 2012)

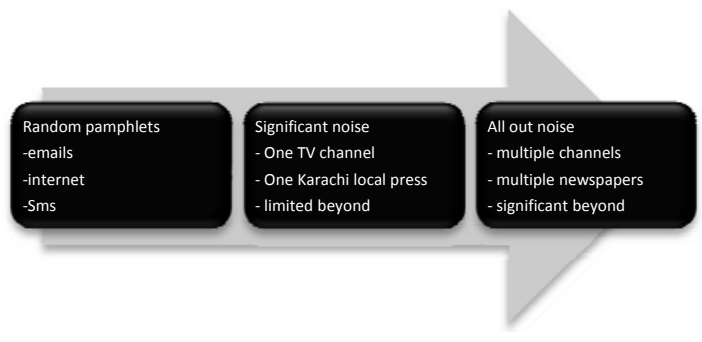

Trade Do nothing
Consumers
Govt bodies
Media

Media

$\begin{array}{ll}\text { Communicate } & \text { Communicate } \\ \text { Do nothing } & \text { Communicate } \\ \text { Do nothing } & \text { Communicate } \\ \text { Respond only } & \text { Communicate }\end{array}$




\section{Creative approach}

Many people, ranging from the young to the old, wanted to believe that these chips they have come to relish are really Halal and hence all that they needed was the official assurance that the chips were in no way Haram. The core of the problem had to be reached. Consequently, in the year 2009, Junaid Jamshed- a former singer turned Born-again Muslim² was very much on the upswing and was gaining popularity with his bayans ${ }^{3}$ and religious sermons. People had grown up with his music and many started following his example. Just to give a glimpse of his popularity, hundreds of people would throng to have a look at him when he would be invited to mosques for his sermons.

Seeing Jamshed's fan following, Frito Lays decided to hire him to endorse their chips and hence to prove to the public that Lays was indeed an edible product and fit to be consumed by Muslims. A TVC was thus shot showing Junaid Jamshed, in his bearded attire, munching on a bag of chips. It was to show that Lays was fit to be consumed by Muslims and thus bears no ingredient which can be deemed Haram.(SK, 2009)

Furthermore, building up on the above formulated strategy, Muhammad Saad Khan opined that "It cannot be denied that Lays has gone through a lot of obstacles with regards to this controversy. However, on a positive note, our Marketing Team has rolled out a new marketing campaign where Junaid Jamshed is endorsing this brand. I am pretty confident that this campaign would bring Lays back on its track".

\section{Effects}

The brand specialist of Lays were initially a bit skeptical about hiring Junaid Jamshed in their endorsement plan but ultimately the doubts vanished as with Jamshed's approval, Lays was once again able to recover its market share and Pepsico's Frito Lay Division now has the $2^{\text {nd }}$ highest Market Share in the snack-food market.(Euromonitor International, 2014)

Pepsi Lays in Pakistan would have never thought of faced by such an issue and misconception, but being a Multinational Organization it should have adapted its marketing tools specifically through public relations to grapple with Halal/Haram conundrum.

Pepsi really needs to do some soul searching about its PR responses. Maybe now is the time to hire a new PR agency and a PR manager who is agile in monitoring the news surrounding the brand in every media and then quickly responding to any potential PR fiasco. (Haque, 2009)

Also, there are a number of clear lessons and learnings for FMCG firms in Pakistan today. These include the fact the awareness that there is no Central body in Pakistan to ensure Halal Certifications on edibles and the government isn't well equipped to handle malicious propaganda. Quite surprisingly, Pakistan also has no proper system to prevent electronic and print media from defaming companies and business groups in Pakistan.

(Brand Manager, 2012)

\footnotetext{
${ }^{2}$ Leaving Music in 2004 Jamshed had started sporting a beard \& gave talks regarding his religious transformation.

'Bayans' in Urdu language means religious talks
} 


\section{References}

Brand Manager, L. (2012, 7 17). Lays PR Crisis. Karachi. E631 : Sodium inosinate. (1999, September 27). Retrieved February 04, 2013, from Food-Info: http://www.foodinfo.net/uk/e/e631.htm

Euromonitor International. (2014). Sweet and Savoury Snacks in Pakistan. Euromonitor International.

Halal Authority Board. (2012). Certification. Retrieved February 18, 2014, from Halal Authority Board: http://www.haboard.com/certification.html

Haque, J. (2009, Sept-Oct). Lay Off! p. 4. Ireland, J., \& Rajabzadeh, S. A. (2011). UAE consumer concerns about halal products. Journal of Islamic Marketing , 274-283.

Khan, M. S. (2012, November 7). Head of Marketing, Foods Pepsi Co Pakistan and Afghanistan. (N. A. Khan, Interviewer)

SANHA. (n.d.). Halaal Certification Process. Retrieved from South African National Halaal Authority: http://www.sanha.co.za/a/index.php?option=com_content\&task=view\&id=48\&Itemid=58 Shafie, S., \& Othman, M. N. (2006). Halal Certification: an international marketing issues and challenges. Proceeding at the International IFSAM VIIIth World Congress , (pp. 28-30).

SK. (2009, June 5th). Pig Fat Controversy: Lays Fight Back with Junaid Jamshed. Brandasybranded Pakistan.

\section{Exhibits}
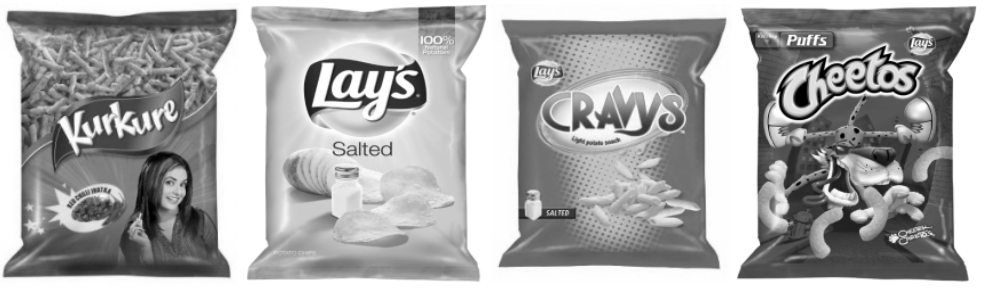

Exhibit 1: Different Chips manufactured by Frito-Lays (Khan, 2012)

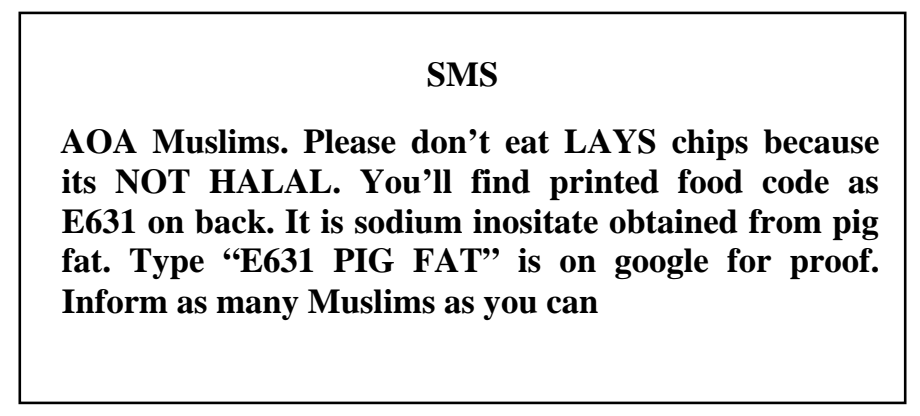

Exhibit 2: A SMS portraying the Halal Controversy revolving around Lays (Khan, 2012) 


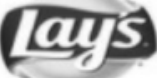

\section{Lays is produced in the Slamic Fepublic of Pakistan using 100\% Falal ingredients}

We assure our consumers and customers that Lays Shacks Pakist an uses only $100 \% \mathrm{Halal}$ ingredients in all its food products. Some news reports from a small section of the media suggest otherwise, and are absolut ely false.

Al our ingredients (including flavor enhancer E631 that is used in Lays Masala, and imported from Thailand) are compliant with strict quality manufact uring and are $100 \% \mathrm{Halal}$. E631 is produced from tapioca st arch which is extracted from a plant called cassava. Pakistan Council of Scientific \& Industrial Research (PCSR), an established government body, has certified that Lays is free of all animal meat fat (i.e. it only contains vegetable fats). Jamia Ashrafia of Pakistan has also declared Lays as $\mathbf{1 0 0 \%}$ Halal. E631 is also certified by the raw material supplier, as well as the Central Islamic Committee of Thailand, as Halal (and the latter has also specifically endorsed the use of the legend "Halal" for such flavor).

Lays chips are produced in Pakistan from the best quality natural potatoes. As a company proud of its superior quality products and best industry practices, Lays Snacks Pakistan is a responsible corporate citizen. We strictly adhere to the local food laws which include only using certified halal ingredients in all our products.

Lays Sacks are sold in many other Muslim count ries including Saudi Arabia, Egypt, UAE and Malaysia. In Pakistan, we employ over 1000 people in the fields of agriculture, production and distribution and are contributing to various social causes like education and health.

For further information, feel free to cont act Mrs. Saima Arshad, Pesearch \& Development Head for Lays Shacks Pakistan at the following email: pak. customerservice@intI. pepsico.com.

Exhibit 3: A public message regarding Lays Ingredients (Khan, 2012)

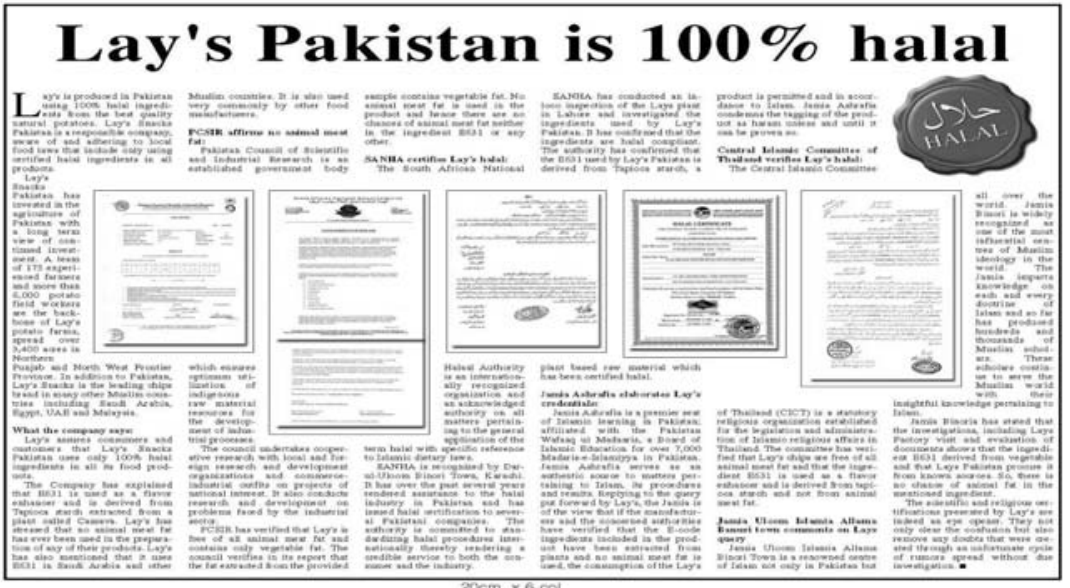

Exhibit 4: A press release saying that "Lays Pakistan is $100 \%$ Halal". (Khan, 2012) 


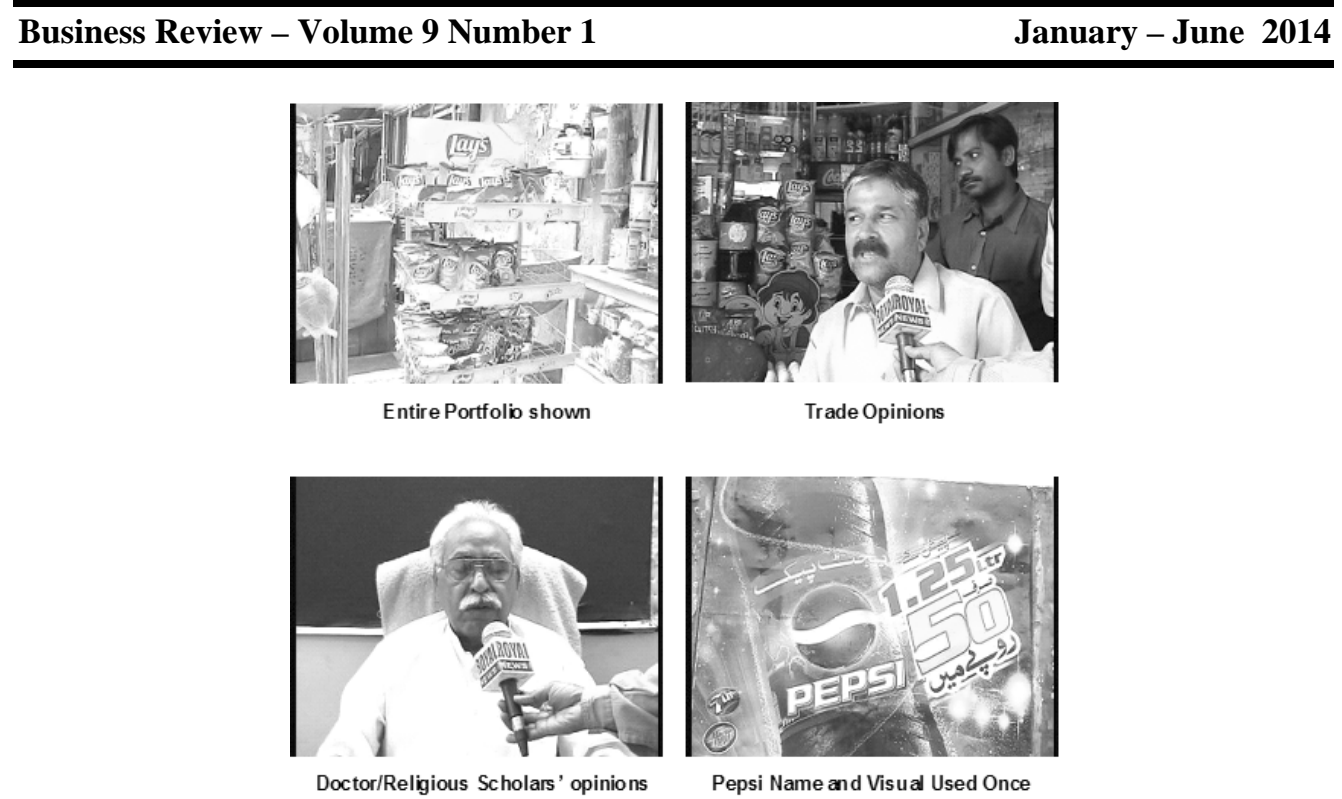

Exhibit 5: Other modes of advertisements (Khan, 2012)

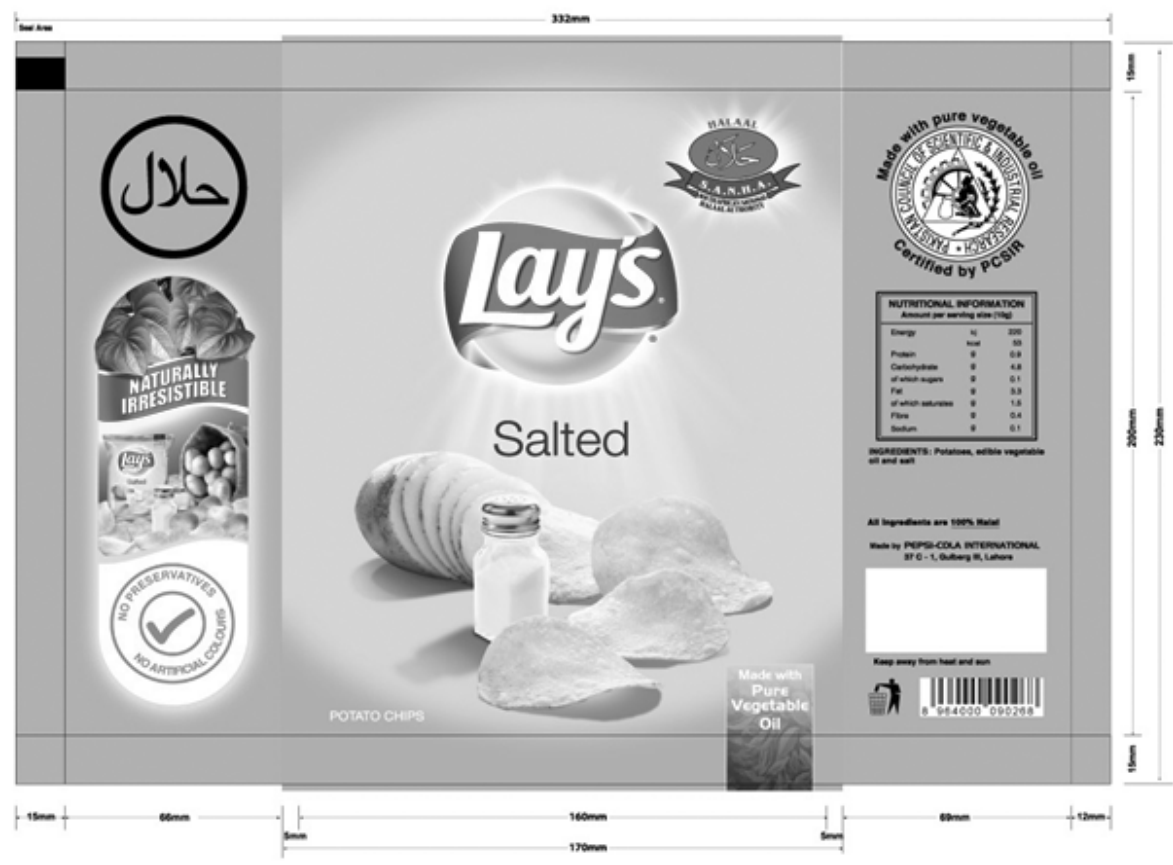

Exhibit 6: Soft Phase in Packaging to Address the 'First Moment of Truth' The packaging includes SANHA as well as PCSIR Endorsement. (Khan, 2012) 


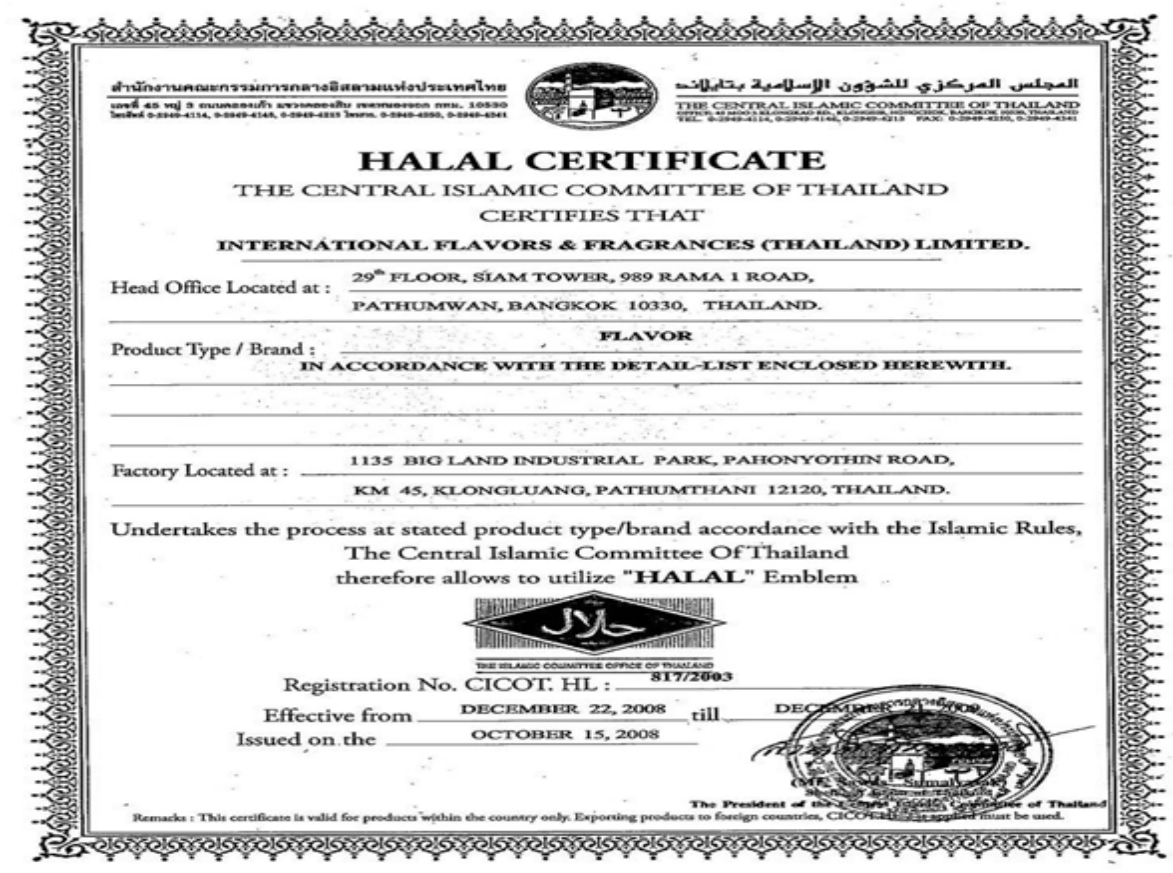

Exhibit 7: Central Islamic Committee of Thailand Certification (Khan, 2012)
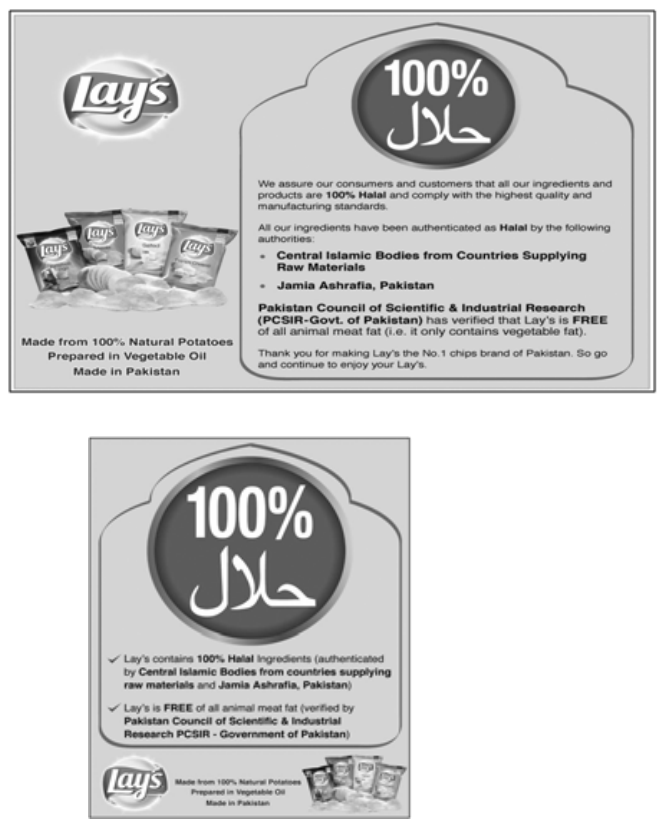

Exhibit 8: Poster Advertisements (Khan, 2012) 